\title{
Chapter 1: \\ Shanghai
}

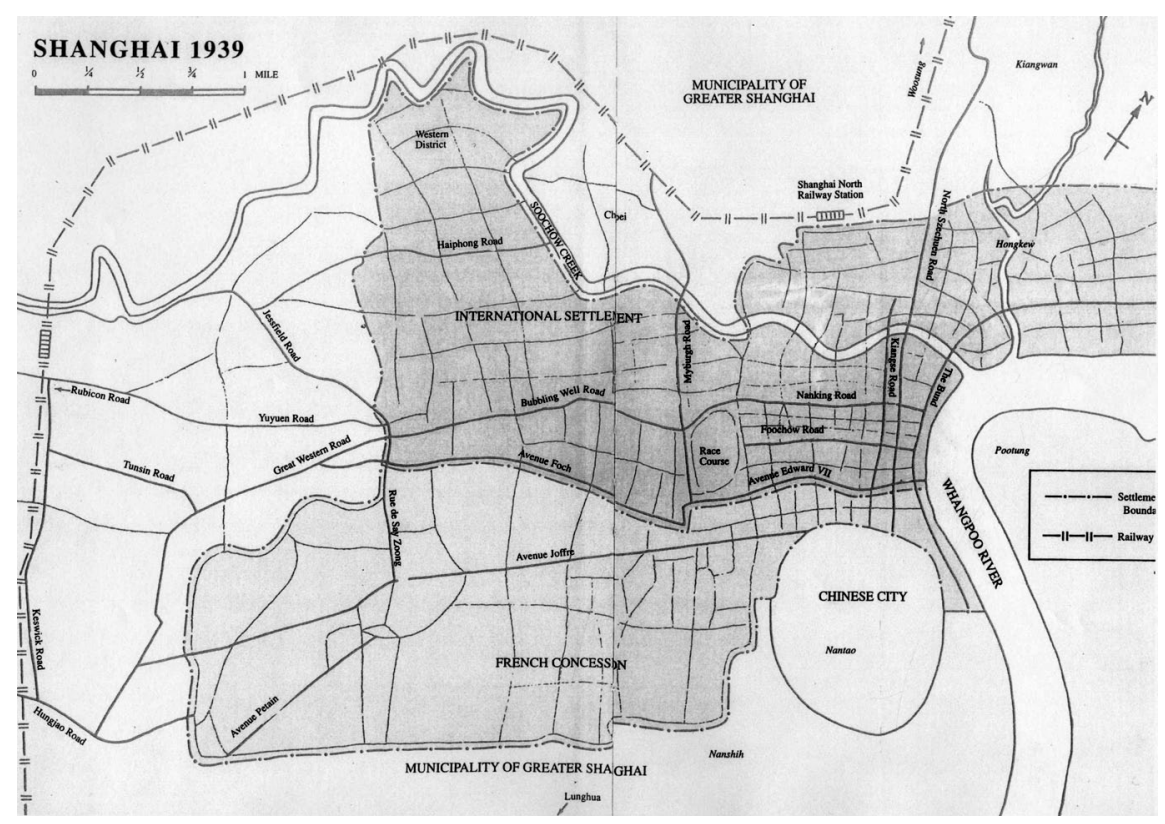

Map 2: "Shanghai 1939." From Tess Johnston and Deke Erh, $A$ Last Look, Western Architecture in Old Shanghai, Hongkong: Old China Hand Press, 1993, frontispiece. By permission of Deke Erh.

The first Central European refugees in 1933 and even the later ones in 1938 were hardly aware of, nor especially curious about Shanghai's long and often important history. For most of them "their" Shanghai consisted of the International Settlement, the French Concession, both with their mixture of populations, and the busy (until the end of 1941) port installations. Few asked themselves when and how the foreign administrations began, why some of Shanghai's areas were under a Chinese administration, or who the Chinese were that they encountered daily, either as destitute beggars or prosperous businessmen, as rickshaw coolies, or as workers in the many factories. To most of them in their vague perception, this was China, and they did not realize that Shanghai was, in fact, like no other Chinese city. It was, as Frederic Wakeman remarks, "one of the most intricate and complicated urban societies in the world."

1 Frederic Wakeman, Jr., "Policing Modern Shanghai," The China Quarterly, no. 115 (September 1988), p. 409.

DOI 10.1515/9783110268188.5, (cc)BY-NC-ND (c) 2017 Irene Eber, published by De Gruyter.

This work is licensed under the Creative Commons Attribution-NonCommercial-NoDerivs 3.0 License. 
Shanghai was a treaty port that grew by degrees from locally leased territory. Before becoming a treaty port, Shanghai had been a walled town, a third class county seat, under the jurisdiction of Nanjing, the provincial capital, and Songjiang, the prefectural capital. Its commercial prosperity had derived from the bourgeoning cotton trade of the Qing dynasty (1644-1912). ${ }^{2}$ Far from being a mere fishing village, walled Shanghai boasted forty-nine bridges, six drawbridges at its six gates, and numerous bridges in the district. Canals crisscrossed the city. ${ }^{3}$ Indeed, when Karl Friedrich August Gützlaff (1803-1851), the adventurer missionary, reached Shanghai in August 1831, he admired not only the prosperous town and its well-off inhabitants, but especially the thousands of junks lying at anchor for loading or unloading. ${ }^{4}$

\section{Beginnings of the Treaty Port}

Much has been written about Shanghai and, except for some general observations, the history of the city's development into a thriving port city need not be repeated here. ${ }^{5}$ First and foremost is the fact that the Opium Wars (18391842) between Great Britain and the Chinese empire resulted in the treaty system in favor of the British. The aim was, as John Fairbank succinctly states, to rid the China coast of the traditional tribute system, that is, to eliminate the Chinese restrictions on foreign trade. Thus, "The first treaties ... emerged as a charter of rights primarily for merchants.” They included almost from the very beginning the principle of extraterritoriality, meaning consular jurisdiction over British nationals. ${ }^{6}$ Shanghai was only one of five treaty ports opened to foreign trade between 1842 and 1844 (there would be others, among them

2 Hanchao Lu, Beyond the Neonlights, Everyday Shanghai in the Early Twentieth Century, Berkeley-Los Angeles: University of California Press, 1999, p. 26.

3 School of Oriental and African Studies, Library, the University of London, CCWM N6/ 10, Pams 6, "General Description of Shanghae [Shanghai] and Its Environs, Extracted from Native Authorities," Shanghae: Printed at the Mission Press, 1850, p. 161.

4 H. Lang, Shanghai Considered Socially, A Lecture, Shanghai: American Presbyterian Mission Press, $1875,2^{\text {nd }}$ ed., pp. 22-24.

5 Among works dealing with Shanghai I might mention William C. Johnstone, The Shanghai Problem, Stanford: Stanford University Press, 1937; Parks M. Coble, The Shanghai Capitalists and the National Government, 1927-1937, Cambridge: Cambridge University Press, 1980; Linda C. Johnson, Shanghai: From Market Town to Treaty Port, 1074-1858, Stanford: Stanford University Press, 1995.

6 John K. Fairbank, "The Creation of the Treaty System," in D. Twitchett and J. K. Fairbank, eds., The Cambridge History of China, Cambridge: Cambridge University Press, 1978, Vol. 10, pp. 214, 217. 
inland treaty ports like Changsha in Hunan and Harbin in Heilongjiang), but Shanghai's growth and increase in population was exceedingly rapid. In the mid-1840s, Shanghai had only around a dozen foreign firms and some one hundred foreigners. A decade later there were approximately seventy firms and more than three hundred foreign residents in Shanghai, in addition to eight consulates. ${ }^{7}$ The increase in foreign commerce and population is also reflected in the number of foreign ships that made port in Shanghai. In 1844, forty-four foreign ships entered Shanghai. By 1849, this number grew to one hundred thirty-three and in 1863 to 3,400 foreign ships. ${ }^{8}$

While at first Protestant missionaries tended to locate their chapels in the walled city, foreigners generally preferred to live in the sparsely populated northern suburbs outside the city walls. This area later became the International Settlement (gonggong zujie) with its favorable location on the Huangpu River. Hongkou, initially an American settlement facing Suzhou Creek merged with the International Settlement in 1863; the French Concession, and the Chinese areas of Zhabei, Pudong, and Nandao, all developed outside the walled Chinese city. ${ }^{9}$ This brings us to the second important fact about Shanghai, namely its growth as a Chinese city and as a city of immigrants. Hanchao Lu remarks that Guangdong and Fujian merchants came to Shanghai during the Qing period and that the encounter with outsiders was an everyday occurrence. Outside influence and the value of commerce caused Shanghai to be less conservative than most other Chinese cities and played a role in its becoming a modern city. ${ }^{10}$ So were, no doubt, also the Ningbo and Zhejiang provincial merchants and workers, with their distinctive cultural traits and social habits, who flocked to Shanghai in search of a better livelihood. ${ }^{11}$ Other Chinese outsiders came in the course of time, and the Taiping rebellion (1850-1864), which spread to the Shanghai countryside, brought numerous refugees to Shanghai in search of protection by the foreigners. By 1865, Lu writes, "The population of the British-American settlement had increased to 92,884. At the same time, almost 50,000 Chinese moved into the French Concession. By the end of the Taiping Rebellion well over 110,000 Chinese had moved into the foreign settlements." 12

7 Ibid., p. 227.

8 Lu, Beyond the Neonlights, p. 27.

9 According to Betty Peh-T'i Wei, Shanghai, Crucible of Modern China, Hong Kong Oxford: Oxford University Press, 1987, p. 84, the wall around the Chinese city was demolished between 1912 and early 1914 .

10 Lu, Beyond the Neonlights, pp. 36-37.

11 Yuen Sang Leong, "Regional Rivalry in Mid-Nineteenth Century Shanghai: Cantonese

vs. Ningpo Men," Ch'ing-shih Wen-t'i, Vol. 4, no. 8 (December 1982), p. 31.

12 Lu, Beyond the Neonlights, p. 36. 
The foreign settlements offered protection from the depredations of the Taipings as well as from other bands of marauders, including soldiers of the imperial army, ${ }^{13}$ but the settlements also held the promise of order and the possibility of pursuing a livelihood with minimal interference. To be sure, the treaties signed with the Western powers were not to China's benefit, yet the Land Regulations of 1845, 1854, and 1869 for governing the International Settlement contributed greatly to tranquilizing the area. ${ }^{14}$ In Shanghai then developed a "mutuality of Sino-foreign interests [which] became the secret of Shanghai's successful independence. By 1854 the ingredients of a new order were present and taking shape in new institutions," argues John Fairbank. He adds that, furthermore, "the result was less an exploitation of China in a colonial style ... than it was a privileged foreign participation in the attempted westernization of Chinese life." ${ }^{15}$ Whether we would call this "westernization" is arguable; nonetheless, it is important to realize that the treaty system also served Chinese interests. This brings us to the third important fact about Shanghai, namely that it was not a colony in the sense of a colony established by the Western powers in Asia. The treaty port did not become the means of extracting profits from Shanghai or for providing jobs only for Western officials. Rather, it also served Chinese interests. In time Shanghai became a modern Chinese city, as will be shown below, and within the metropolis a Chinese middle class and a Chinese capitalist class developed. No doubt, Shanghai's favorable location was a factor. There were port facilities and a safe harbor on the $\mathrm{Hu}$ angpu; it was at the crossroads of domestic and international trade and shipping; Shanghai could and did for a time serve as a shipping center for all of East Asia. In 1846 Shanghai was described as "not only a point of great trade in imports and exports, but also an emporium where there is an exchange of national and foreign commodities between the southern and northern parts of the empire." 16

13 Such was the occupation of the walled city by the Small Sword Society (Xiaodao hui) in 1853 and the arrival of the imperial army in 1855, ending with the so-called Battle of Muddy Flat. See "The Battle of Muddy Flat," pamphlet, Shanghai: Printed and Published at the North China Herald Office, 1904.

14 The Land Regulations and their revisions were considered a "constitution" for Shanghai until 1943. Aside from its various regulations, deleted and amended in its several revisions, the Land Regulations also spelled out who was qualified to vote in municipal elections. The French Concession promulgated its own regulations, generally referred to as Règlement, in 1868.

15 Fairbank, "Creation of the Chinese Treaty System," pp. 240, 263.

16 "Notices of Shang-hai: Its Position and Extent; Its Houses, Public Buildings, Gardens, Population, Commerce, etc.," Chinese Recorder, Vol. 15, no. 9 (September 1846), p. 469. 
Yet - and this is the fourth important fact about Shanghai - the city developed not as a unified urban complex, but as a fragmented collection of interlocking and interrelated areas with their own administrations. The Shanghai Municipal Council (SMC) was the governing body of the International Settlement, which in time was composed of British, American, Chinese, and Japanese officials. The SMC was, however, not a sovereign body and its responsibilities were merely administrative. The local authority for the SMC was the Consular Body which was responsible, in turn, to its respective governments. The French Concession was governed by the French Consul General, who had an advisory body, but whose authority was derived directly from the French government. The third governing body was the Chinese Municipal Administration, which governed the areas of Nandao, Pudong, Zhabei, Jiangwan, and Wusong. This administrative system was, in effect, set up only in July 1927 under Mayor Huang Fu (1880-1936), when the Nationalist government of the Republic of China assumed power in Nanjing. ${ }^{17}$ Each area, furthermore, had its own police force: the Shanghai Municipal Police (SMP) in the International Settlement, the Frenchtown Concession Police, and the Nationalist Garrison Command Military Police in the Chinese areas. Despite having its own jurisdiction, each police force had to work in cooperation with the others on routine criminal cases. This was especially true in the 1930s when the power of Chinese gangs grew in the French Concession and the Chinese areas. ${ }^{18}$ However, coordination in political cases was less common. ${ }^{19}$

But coming to Shanghai from other provinces - Zhejiang, Guangdong, or Jiangnan - did not automatically turn a person into a Shanghainese, a Shanghairen. Whether as villagers now turned workers, small merchants, clerks, or artisans, the new urbanites retained their native-place identities, in addition to assuming new ones. Native-place associations (huiguan) and the modernized forms that they developed, as well as the native-place networks, could lead to employment, but were also at the basis of later gangster organizations. Indeed, even Shanghai student organizations with their modernizing and patriotic aims were organized as native-place associations (tongxianghui). While rejecting traditionalistic practices, "they did not reject the principle of organization accord-

17 Robert W. Barnett, Economic Shanghai: Hostage to Politics, 1937-1941, New York: Institute for Pacific Relations, 1941, pp. 5-7. The Japanese were not part of the Treaty Powers, but had assumed increasing control over Hongkou (part of the International Settlement) after 1932, as will be discussed below.

18 Wakeman, Jr., "Policing Modern Shanghai," p. 409.

19 Bernard Wasserstein, Secret War in Shanghai, London: Profile Books, 1998, p. 62, observes that "the two neighboring police authorities ... frequently behaved more like enemies than allies." The SMP was often highly suspicious of the French police. 
ing to native-place origin." ${ }^{20}$ This combination of new forms and old patterns was characteristic of Shanghai in its growth into a modern metropolis. And it is this unique development, in addition to the city's treaty port status, as we shall see below, that provided the opportunity for the settlement of different Jewish communities.

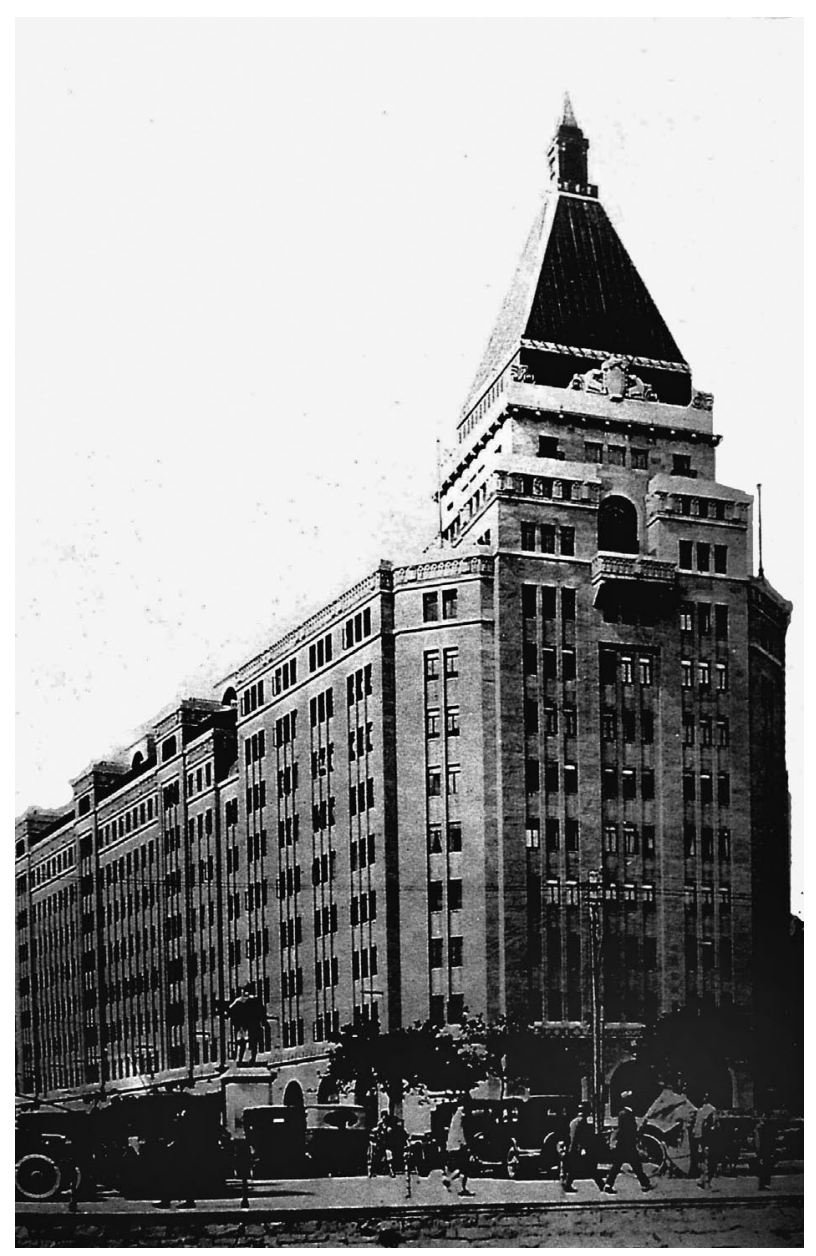

Fig. 1: The Cathay Hotel built by Sir Victor Sassoon in 1929. Courtesy Tess Johnston and Deke Erh, $A$ Last Look: Western Architecture in Old Shanghai, Hong Kong: Old China Hand Press, 1993, p. 96. By permission.

20 Bryna Goodman, "New Culture, Old Habits, Native-Place Organization and the May Fourth Movement," in Frederic Wakeman, Jr., and Wen-hsin Yeh, eds., Shanghai Sojourners, Berkeley: Institute of East Asian Studies, University of California Press, 1992, p. 77; see also Frederic Wakeman, Jr. and Wen-hsin Yeh, “Introduction,” pp. 1-14. 


\section{Shanghai until the Sino-Japanese War of 1937}

Hanchao Lu has argued persuasively in Beyond the Neonlights that Shanghai developed as a modern city under the Western impact, but beneath it or within this ever increasing modernity, a Chinese way of life for most of the population remained profoundly traditional. Or, to put it another way, the Chinese traditional way of life continued in Shanghai and changed in accordance with urban, not western demands.

Western style amenities were introduced into the concessions soon after the opening of the treaty port. Thus, Western-style streets began to appear as early as 1856, gas lighting in 1865 , telephones in 1881, electricity in 1882, running water in 1884, automobiles in 1901, and tramways in 1908. The first tram ran on Nanking Road (today Nanjing Donglu), extending from the Bund (today Zongshan Dongyilu) to Tibet Road (today Xizanglu). The first horse race, the British sport for which Shanghai became famous together with its race course, was probably held in $1846 .{ }^{21}$ However, the Chinese refugees who came at first, and most of the others, Chinese and Westerners alike, lived not on Shanghai's fashionable streets, but in the alleys and the alleyway houses (lilong fangzi), as did the majority of Central European refugees after they arrived in large numbers in 1938.

Alleyway houses began to be built after 1880, in accordance with a new, non-traditional, design. There were those that had modern amenities (flush toilets and gas) and those that did not. Both older and newer types were usually two- or three-story brick buildings (sometimes with gardens) and were built in rows along the alleys. Alleyways sprawled all over the city and its houses were inhabited by urbanites (xiao shimin), not the truly poor, who lived in shanty towns. ${ }^{22}$ Coolies, of whom there were 100.000 or more by the 1930 s in Shanghai, beggars, and people with unsteady incomes lived in the shanty towns, sometimes temporarily, when lack of income caused them to return to their native villages. Alleys formed neighborhoods for which stores carrying everyday needs were indispensable. There were the rice and coal stores, the sesame cake and hot water stores ('tiger stoves', laohuzao), which never closed. ${ }^{23}$ In short, a person's life could be lived in the alley neighborhood

21 Leo Ou-fan Lee, Shanghai Modern, The Flowering of Urban Culture in China, 19301945, Cambridge: Harvard University Press, 1999, pp. 7, 31.

22 Lu, Beyond the Neonlights, p. 2.

23 Hanchao Lu, "Away from Nanking Road: Small Stores and Neighborhood Life in Modern Shanghai," The Journal of Asian Studies, Vol. 54, no. 1 (February 1995), pp. 93-123. 
without ever venturing into the westernized sections of Shanghai - the famous Bund with its foreign banks and Nanking Road and its department stores - or into those parts, like the western part of Bubbling Well Road (today Nanjingxilu), where wealthy Westerners and Chinese lived.

The city therefore was fragmented into numerous small communities wherein a life of moderate comfort could be obtained and maintained without venturing into the outside world - just a few blocks away. To many residents the few blocks around their homes were what the 'city' meant to them ... ${ }^{24}$

The wealthy, although a small percentage of the more than 3.5 million Shanghai population by the 1930s, were nonetheless an important elite segment of Chinese society. Hailing from diverse native place backgrounds, these urban elites were either self-employed or were active in modern banking, industry, communication and transportation. Shanghai was the seat of large trading firms - as many as twenty eight foreign banks had agents or head offices in Shanghai by 1919 - and major foreign cotton mills employed thousands of Chinese workers. As Marie Bergère writes, a major new urban class originated in Shanghai, an intelligentsia, a business, and a working class. Before July 1937, which marked the beginning of the so-called "undeclared war" (the SinoJapanese War), fully half of China's modern factories were in Shanghai; ${ }^{25}$ doctors of Chinese and western medicine, professionals of many kinds as well as investors, publishers and writers flocked to Shanghai. In the 1930s, the city was both a capitalist and a cultural center. Not to be forgotten are Shanghai's universities, of which the first Protestant missionary college (at the beginning more a high school than a college) was St. John's, founded in $1879 .{ }^{26}$ Other institutions of higher education were founded after the turn of the century, until by 1934 Shanghai had twenty- five institutions of higher education (compared with Beijing's seventeen), private as well as public, ${ }^{27}$ and 10,520 students. ${ }^{28}$ Although Shanghai was not considered the intellectual center that

24 Lu, Beyond the Neonlights, p. 15.

25 Lu, Beyond the Neonlights, pp. 58-59.

26 Irene Eber, The Jewish Bishop and the Chinese Bible, S.I.J. Schereschewsky (1831-1906), Leiden-Boston: Brill, 1999, pp. 133-137. For the important university that it became during the Republican period, see Ceng Xubai, "Sili Sheng Yuehan daxue (Private St. John's University)," in Zhonghua minguo daxue shi (Record of Chinese national universities), Taibei: Wenhua, 1952, Vol. 2, pp. 397-403.

27 Wen-hsin Yeh, The Alienated Academy, Culture and Politics in Republican China, 1919-1937, Cambridge-London: Council on East Asian Studies, Harvard University Press, 1990, p. 281.

28 Bergére, “The Other China," p. 20. 
Beijing (then Beiping) was, neither was it solely devoted to business and money.

Not only did the universities and their active student bodies contribute to the lively atmosphere that characterized Shanghai in the 1930s, its large publishing industry and its extensive popular press, both foreign and Chinese, were an important element in the city's life. This is a large subject to which I cannot do justice in these pages except to point out several aspects worth noting. The Commercial Press (Shangwu yinshu guan, established in 1897), although best known, was only one of many hundreds of presses in Shanghai. Moreover, the city was famous for its bookstores, concentrated along Fuzhou and Henan Roads in the International Settlement. "No city in Republican China enjoyed more freedom of the press ..." writes $\mathrm{Lu}^{29}$ The first modern Chinese newspaper, Shenbao (Shanghai News) was published in Shanghai from 1872 on, as were such widely read journals as Dongfang zazhi (Eastern Miscellany) and Xiaoshuo yuebao (Short Story Magazine). In the first readers would find essays about other places and people and in the second, translations from Western literature. ${ }^{30}$

There were Chinese dailies, whether as morning or as evening papers, as well as the foreign press, especially English-language dailies like the first American newspaper, the China Press (founded in 1911) and the British, the North China Daily News (first appeared in 1850). Dailies provided not only allimportant shipping news - the arrival and departure of ships necessary for business transactions - but also news about events in China and abroad. The Chinese and foreign press had a significant, if not revolutionary, impact on political and cultural life especially in the 1930s. So did even such short-lived weeklies as the China Forum, which aimed at creating a new awareness about China, its politics and culture, among Chinese and foreign readers. ${ }^{31}$ Freedom of the press existed in the treaty port, yet the journalists and writers in these papers often endangered their lives, especially in the 1930s. They were not outside the political system, they had political roles which were often at odds

29 Lu, Beyond the Neonlights, p. 60.

30 A number of important writers and translators of the Republican period lived in Shanghai for longer or shorter periods of time. Among them Mao Dun (Shen Yanbing, 1896-1981), Yü Dafu (1896-1945), and Lu Xun (Zhou Shuren, 1891-1936). For a valuable discussion of the literary publishing scene, see Lee, Shanghai Modern, pp. 120-150. 31 The China Forum was founded by Harold R. Isaacs (1910-1985) in January 1932. It ceased publication exactly two years later, January 1934, after thirty-nine issues, the last sixteen bilingually in Chinese and English. Harold R. Isaacs, Re-Encounters in China, Notes of a Journey in a Time Capsule, Armonk, N.Y.-London: M. E. Sharpe, Inc., 1985, pp. $13-26$. 
with those in power, or they ran afoul of censors. ${ }^{32}$ Significant for our story is the fact that coming into this environment of publishing and printing, it is not surprising to find refugee entrepreneurs also engaged in publishing shortly after their arrival.

Aside from the print culture, Shanghai boasted a flourishing motion picture industry as well as a large number of movie theaters, located in various parts of the city. A foreigner could see the latest Hollywood productions as advertised in such papers as the Shanghai Evening Post and Mercury, or Chinese films produced in Shanghai's film studios and shown in theaters in Shanghai's Chinese sections. According to Leo Lee, "the movie theaters created both the material conditions and a cultural climate for movie going as a new habit of urban life, without which the development of the native Chinese cinema would have been impossible." ${ }^{33}$ Although Shanghai's workers or coolies who eked out a meager living would not have been able to afford the price of a ticket, the foreign population and the growing middle class undoubtedly took advantage of the new art form. The production of Chinese films in Shanghai's studios and the fact that eight of some forty movie theaters were in the Chinese portions of the city, clearly indicates a substantial Chinese film audience. $^{34}$

Yet, beneath the glittering facades of the banking houses on the Bund, fashionable department stores on Nanking Road, or the opulent mansions on Bubbling Well Road new forces were gradually taking shape that affected the foreign and the Chinese business communities. The prosperous foreign businessmen were now joined by a steadily increasing Russian refugee population which arrived in Shanghai after the Russian October Revolution of 1917. At the same time, the Japanese population also grew in size in the 1920s, settling for the most part in Hongkou. Unlike the destitute Russians, the Japanese were mainly small business and tradesmen, and both will be discussed below. Aside from the Japanese, although numerically far smaller, other Asians, like Indians, Koreans, and Taiwanese, also trickled into the treaty port in search of new opportunities. Europeans too were no longer only British, American, or

32 Stephen R. McKinnon, "Toward a History of the Chinese Press in the Republican Period,” Modern China, Vol. 23, no. 1 (January 1997), pp. 5-11.

33 Lee, Shanghai Modern, p. 84.

34 Ibid., p. 357, note 10. Chinese films included silent films and increasingly "talkies" in the 1930s. Some were based on traditional or current popular novels as, for example, Lianai yu wuyi (Love and Duty) by Luo Chen. The film dates from 1931, but the novel was a Chinese translation from French (?) and was written by a Jewish woman from Poland, named S. Rosenthal, then living in Beijing. I thank Professor Yomi Braester for making the film available to me. 
French. They now came from many different countries and were often migrants from other parts of Asia or Africa. They engaged in what John Darwent calls "serial migration," an important element in European colonialism. ${ }^{35}$ Many Europeans were no longer temporary residents, returning to their home countries after a tour of duty. On the contrary, they considered Shanghai home and planned to remain there. The treaty system and its denationalized order ${ }^{36}$ suited many foreigners who referred to themselves as Shanghailanders, rather than as the nationals of the countries from which they had come.

Although the 1920s were years of unprecedented growth and prosperity as an international port and industrial center, Shanghai experienced its first challenge in March 1927, when Chiang Kai-shek's (Jiang Jieshi, 1887-1975) Nationalist troops entered Shanghai and when in the following month his troops broke the power of the leftist and communist labor unions, launching a ferocious campaign against Shanghai's workers. ${ }^{37}$ In October 1928, Chiang established Nanjing as the capital of his Nationalist government. But the "Nanking decade," as it is known in Chinese history (actually only some nine years) affected the Chinese capitalists in Shanghai more than it did the Western businessmen. Nonetheless, these were turbulent years of ferment within China and of increasing friction and encroachments by the new East Asian power - Japan.

Yet, it would seem in retrospect that both the Chinese and Western businessmen failed to read and interpret the ominous signs. Only three years after the establishment of the Nanjing regime, which led to a large role for the Nationalist party bureaucrats in Shanghai affairs, the Japanese occupied Manchuria, China's three northeastern provinces of Liaoning, Jilin, and Heilongjiang. There was no resistance and on September 18, 1931, Japanese troops occupied the major cities of southern Manchuria within hours. Some weeks later, a puppet government was established in China's northeast. ${ }^{38}$ On March 1, 1934, Henry Puyi (1906-1967), scion of the last dynasty, the Qing (1644-1912), was formally crowned emperor of the state of Manchukuo.

35 John Darwent, “Afterword: A Colonial World," in Robert Bickers and Christian Henriot, eds., New Frontiers, Imperialism's New Communities in East Asia, 1842-1953, Manchester-New York: Manchester University Press, 2000, pp. 251-253.

36 Bickers and Henriot, "Introduction," in New Frontiers, p. 5.

37 The so-called Northern Expedition, of which Chiang's sweep into Shanghai was the aftermath, will not be discussed in these pages. For Chiang's break with the communists, see the documentary collection by C. Martin Wilbur and Julie Lien-ying How, eds., Documents on Communism, Nationalism, and Soviet Advisers in China 1918-1927, New York: Columbia University Press, 1956, and Jonathan D. Spence, The Search for Modern China, New York-London: W. W. Norton and Co., 1990, pp. 341-360. 38 Parks M. Coble, Facing Japan, Chinese Politics and Japanese Imperialism, 19311937, Cambridge: Council of East Asian Studies, Harvard University Press, 1991, p. 11. 
Manchuria was a long way from Shanghai and repercussions from the creation of the puppet state may not have been felt strongly in Shanghai. The matter was entirely different, however, some months later when Japanese forces clashed with the Chinese Nineteenth Route Army in Shanghai's Zhabei district at the end of January 1932. ${ }^{39}$ During the fighting, which lasted until March 3, 1932, large portions of Zhabei were laid waste; civilian casualties from indiscriminate Japanese bombing were extremely high; the Commercial Press together with its important library was destroyed; factories and universities suffered partial or complete destruction. ${ }^{40}$

The final link in this chain of events was the outbreak of the Sino-Japanese war in July 1937. First in the north, it was followed one month later by the fierce battle for Shanghai. Parks Coble writes that "The bloody Battle of Shanghai would become the most intense conflict since Verdun in World War I." ${ }^{41}$ Although the International Settlement and the French Concession were largely spared, Zhabei bore once again the brunt of the fighting, as did large areas of Hongkou. The battle in and around Shanghai lasted well into the winter months with a staggering cost of Chinese civilian and army casualties. To the foreigners in Shanghai the bombardment of August 14, 1937, brought home the fact that they were no longer as invulnerable as they might have thought. According to an eyewitness, the Chinese attempt to bombard a Japanese warship on that Saturday morning, went as follows:

Suddenly there was a roar of aircraft as a half-dozen or so low-flying planes appeared ... dropping a number of bombs, which sent up a great fountain of mud and water but did not appear to hit any ships. All the Japanese warships opened up at the planes ... but although the air was full of bursts and flying pieces of metal ... miraculously nobody and nothing of importance on the river seemed to have been hit.

Civilians were not so lucky. In the afternoon of that same day, another formation of Chinese planes appeared and bombs fell on Nanking Road and a crowded square on Avenue Edward VII outside the Great World Theatre. For

39 Ibid., pp. 41-43. Coble describes the events that led up to what is usually referred to as the Shanghai Incident. The Japanese, being vastly outnumbered by the Chinese forces, had not expected the fierce resistance they encountered.

40 Ibid., p. 48. See also He Pingsong, "Shangwu yin shuguan beihui jilue, (General account of destruction by fire of the Commercial Press)," Dongfang zazhi, Vol. 29, no. 4 (October 16, 1932), pp. 3-9, who describes in detail the destruction of the library and its works on January 28.

41 Parks M. Coble, Chinese Capitalists in Japan's New Order, The Occupied Lower Yangzi, 1937-1945, Berkeley-London: University of California Press, 2003, p. 11. 
the next three months, Shanghai ports were closed to international traffic. ${ }^{42}$ During this time, aside from the countless people made homeless during the bombardment, Chinese refugees from the surrounding countryside began arriving in overwhelming numbers in the International Settlement and, less than a year later, Central European refugees arrived by sea in ever increasing numbers. Before discussing the new difficulties created for the foreign community by the war and the refugees, I want to turn to some of the ethnic communities within Shanghai's foreign enclave.

\section{Baghdadi (Sephardi) and Russian (Ashkenazi) Jews}

At its height more than fifty different nationalities were represented in Shanghai's foreign community, and among the earliest newcomers, British and American, were the Sephardi or Baghdadi Jews, though not all hailed from Iraq. They came mostly via Bombay where they had prosperous business firms, and their aim was to establish branches in the newly opened treaty port. ${ }^{43}$ Elias David Sassoon (1820-1880) arrived in Shanghai as early as 1844 and eventually built up a commercial empire along the China coast. Other members of the Sassoon family followed, contributing to the various Sassoon enterprises and making this one of the wealthiest families in Shanghai. ${ }^{44}$ By 1862 a small Jewish community had already come into being, necessitating the establishment of a cemetery. The cemetery was in use until 1919 when the need for a new one arose..$^{45}$ An early colorful personality on the Shanghai scene was Silas

\footnotetext{
42 W.J. Moore, Shanghai Century or "Tungsha Flats to Soochow Cree," Ilfracombe, Devon: Arthur H. Stockwell, Ltd., n.d., pp. 35-37. For an eyewitness account of the events of August 14, see also John B. Powell, My Twenty-Five Years in China, New York; The Macmillan Co., 1945, pp. 298-303.
}

43 "List of Commercial Houses, Agents, etc.," Chinese Repository, Vol. 15, no. 1 (January 1846), p. 7. Eliahoo [Elias] D. Sassoon established a firm in Canton with Moses Dahood and A. d'Miranda, the latter probably as agents.

44 For a detailed history of this important family, see Maisie Meyer, From the Rivers of Babylon to the Whangpoo, Lanham-New York: University Press of America, Inc., 2003, pp. 11-16; also Mendel Brown, “The Modern Jews of China - Shanghai - II," Israel's Messenger, Vol. 33, no. 9, December 4, 1936, p. 10.

45 Brown, "The Modern Jews of China." Brown still saw this cemetery on Mohawk Road (today Huangpin Beilu) opposite the race course and its tombstones. He noted that the first burial took place in 1863 and was that of Joseph Rahamim (son of Isaac Reuben) who died at the age of 25 . This cemetery and three others in Shanghai have since disappeared together with most of the tombstones after being moved to Qingpu county in the late 1950s. Tess Johnston was the first to alert readers to Jewish gravestones scattered in fields and villages. Tess Johnston and Deke Erh, God and Country, Western 
Aaron Hardoon (1851?-1931), whose life is one of rags to riches. Arriving in Shanghai in 1874, he was employed by David Sassoon and Co. as a rent collector and watchman. Less than thirty years later Hardoon was on his way to becoming one of Shanghai's major landowners, and by 1916, according to Chiara Betta's account, he owned most of the properties along Nanking Road. At the time of his death he may have been the richest foreigner in East Asia. ${ }^{46}$ Silas Hardoon was, however, not only known for his fabulous wealth. He and his wife, Luo Jialing (also known as Liza, 1864-1941) ${ }^{47}$ supported and contributed to a variety of Chinese causes and institutions. ${ }^{48}$ Although the Hardoons, no doubt, were more interested in China and the Chinese than most Jewish families, others too contributed to Chinese life. Among them the Kadoorie family is noteworthy. Sir Ellis Kadoorie (1854-1922) established six schools in Hong Kong, Shanghai, and Canton (Guangzhou), three of which were in Shanghai. The aim was to provide free education for poor Chinese that included Western (arithmetic, map drawing, etc.) as well as Chinese subjects. ${ }^{49}$ Despite boasting more wealthy families than any other Jewish community in Shanghai - indeed, quite out of proportion, for the Baghdadis never numbered more than approximately 1,000 persons - there were also the less well-off and poor Baghdadi Jews. These tended to find employment in the firms of the affluent families. Class differences existed in the Baghdadi community that were also manifested in the extent of westernization, with the upper classes taking more readily to western ways in distinction to the poorer, lower ones. ${ }^{50}$

Religious Architecture in Old China, Hong Kong: Old China Hand Press, 1996, pp. 123-[125]. For more about the cemeteries and current efforts to recover gravestones, see below, ch. 4 .

46 Chiara Betta, "Myth and Memory. Chinese Portrayals of Silas Aaron Hardoon, Luo Jialing and the Aili Garden Between 1924 and 1925," in Roman Malek, ed., From Kaifeng ... to Shanghai, Jews in China, Sankt Augustin: Monumenta Serica Institute, 2000, p. 377. For a largely anecdotal account, see also Xu Zhucheng, Hatong waizhuan (Hardoon's unofficial biography), Hong Kong: Wuxing jishu baoshe, 1982. 47 For the biography of Liza Hardoon, see Ephraim Selmanson, "Liza Hardoon, die Geschichte der reichsten Erbin Asiens," Shanghai Morgenpost, November 16, 1941, p. 7. 48 Among these especially is the Patriotic School (Aiguo xueshe) in Shanghai, with which major personalities of the Republican period were associated. See Mary Backus Rankin, Early Chinese Revolutionaries, Radical Intellectuals in Shanghai and Chekiang, 1902-1911, Cambridge: Harvard University Press, 1971, pp. 61-69.

49 Arnold Wright, ed., Twentieth Century Impressions of Hongkong, Shanghai, and Other Treaty Ports of China: Their History, People, Commerce, Industries and Resources, London: Lloyd's Greater Britain Publishing Co., Ltd., 1908, pp. 127-128. 50 Chiara Betta, "From Orientals to Imagined Britons: Baghdadi Jews in Shanghai," Modern Asian Studies, Vol. 37, no. 4 (2003), p. 1019. 


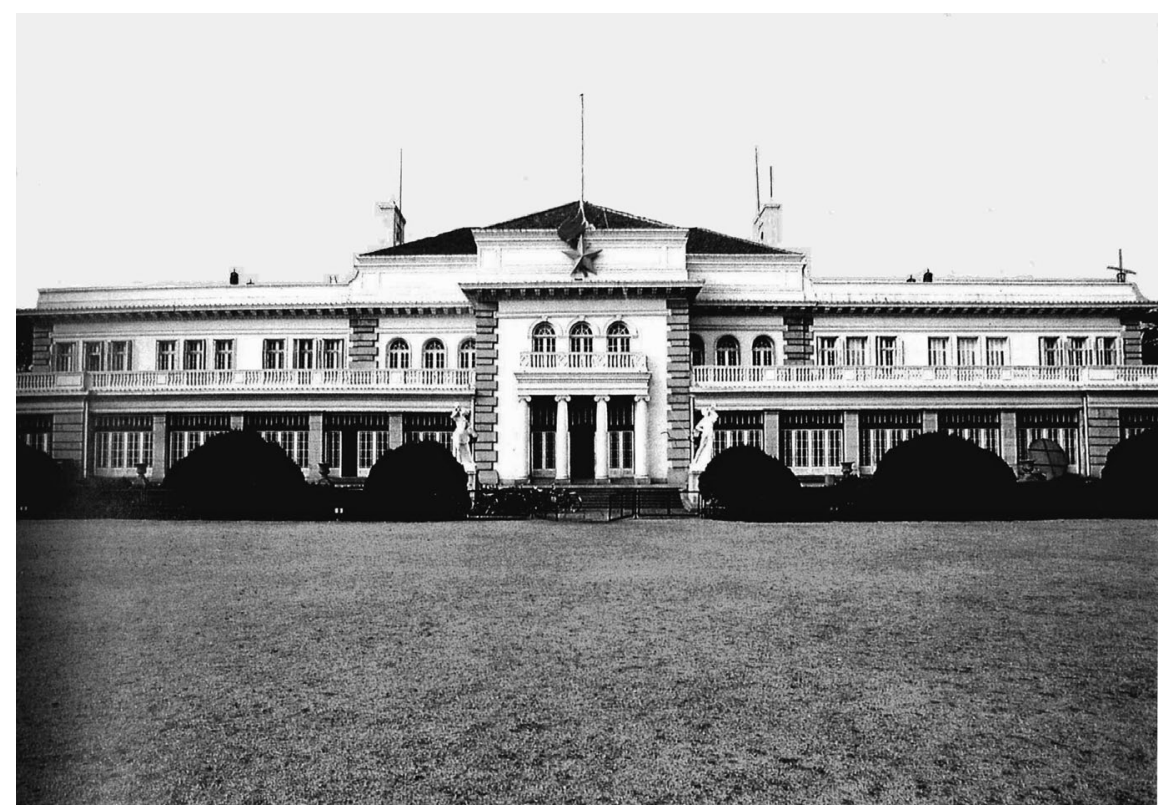

Fig. 2: Marble Hall, home of the Kadoorie family, completed in 1924, now the “Children's Palace." Tess Johnston and Deke Erh, A Last Look: Western Architecture in Old Shanghai, Hong Kong: Old China Hand Press, 1993, p. 17. By permission.

A study of the Shanghai tycoons and their far-flung business connections is still lacking, nor do we know, except for fragments, what their connections were to the Shanghai Chinese capitalists in the 1920s. Yet, clearly their adaptability to changing circumstances is admirable. The opium trade had initially attracted Baghdadi Jewish entrepreneurs to Shanghai and other treaty ports. The Sassoons even owned their own opium clippers, ${ }^{51}$ but they soon branched out into other commodities and business ventures.

Baghdadi Jews settled for the most part in the International Settlement where they also had their businesses. Although their native tongue was JudaeoArabic, they rapidly acquired English as their major language, and their main organ, Israel's Messenger, published between 1904 and 1941, was printed in English. ${ }^{52}$ Synagogue life developed but slowly and the magnificent structure

51 Wright, Twentieth Century Impressions, p. 224, and Meyer, From the Rivers of Babylon, pp. 57-68.

52 The journal was actually considered the official organ of the Shanghai Zionist Association and carried news of the several Jewish communities in China.

It suspended publication from 1910 to 1918 . First published as a fortnightly, it became a monthly in 1921. See Meyer, From the Rivers of Babylon, p. 186. 
of Ohel Rachel on Seymour Road (still standing on today's Sha'anxi Beilu Road) was consecrated only in 1921. At the same time the Baghdadi community also appointed its first rabbi, W. Hirsch. In 1927, Silas A. Hardoon donated the Beth Aharon synagogue in Hongkou on Museum Road (now demolished). Although the earlier prayer halls, Beth El on Peking Road (today Beijing Lu) and Shearith Israel on Seward Road (today Changzhi Donglu) had been important in providing meeting places for religious life, the new synagogues made possible a new solidarity, as Maisie Meyer remarks. ${ }^{53}$ Jewish traditions and observances were maintained by the Baghdadis in Shanghai, but tended to weaken as time went on. This does not mean that the Baghdadis assimilated, or intermarried, becoming a part of the British environment. Rather, certain practices like the Sabbath closure of businesses were no longer strictly observed by all Baghdadis, yet they did not forget their Jewish antecedents nor, indeed, their identity as Sephardim. On the other hand, similar to some major businessmen in the treaty port, a number of Baghdadis had close connections to British governing circles and the Shanghai Municipal Council. After the outbreak of the Sino-Japanese war in July 1937 and the increasingly dominant role assumed by Japan in Shanghai affairs, these relationships exhibited new complexities. The political roles of the Baghdadis cannot, however, be explored in these pages.

The complex relations are especially evident in their support of charitable causes. Until the arrival of large numbers of refugees toward the end of 1938, when the burden became too heavy for the wealthy Sephardi families and when aid from abroad was required, the Sassoon, Kadoorie, Abraham, and Joseph families were the chief support of several Jewish charitable organizations, such as the Shanghai Hebrew Relief Society and the Free Loan Society. But by 1938 these barely scraped by on locally raised donations, as the minutes of the "Investigating Committee for International Sufferers" show. ${ }^{54}$

Later that year, in October 1938, therefore a new committee under Sephardi leadership was established during a meeting in the office of Sir Elly Kadoorie (Reuben Ezekiel) and Sons. "The Committee for the Assistance of European Jewish Refugees in Shanghai" (CAEJR) had a new organizational structure, first with Michel Speelman (1877-?) and later with Ellis Hayim (1894-1977) as chairman. ${ }^{55}$ The Public Relations Committee of the new organization was of major

53 Meyer, From the Rivers of Babylon, pp. 95-100.

54 JDC, file 456, "Investigating Committee for International Sufferers," minutes of the $5^{\text {th }}$ meeting, January $5,1938$.

55 Speelman was a Dutch Jew, undoubtedly of Sephardi parentage. He was a prominent banker and was active in Nationalist government circles. There is a brief biography in George F.M. Nellist, Men of Shanghai and North China. A Standard Biographical Work, 
importance and included R. D. (Reuben David) Abraham. It was this committee which was to be in contact with the SMC, the French Municipal Council, the Japanese authorities, as well as with the Joint Distribution Committee (JDC) in New York and Paris, the London Council for German Jewry, and other Jewish organizations. ${ }^{56}$ The letter does not state, but it can be easily assumed, that the spokesmen for the refugees had to be English speakers (Speelman also spoke French). Furthermore, they had to be prominent members of the business community who were well known in official circles. Neither the refugees though many may have held prominent positions in Germany and Austria nor members of the Russian (Ashkenazi) community qualified on both counts. The letter also indicates that the attempt would be made to coordinate relief efforts and with the Relief Society for German Jews (Hilfsfond für deutsche Juden), ${ }^{57}$ and the "International Committee" (both to be discussed below) as well as with the newly formed CAEJR. The amalgamated efforts never actually materialized, and I will have occasion to return to this subject later.

Let us now turn to the Russian Jewish community which in time became larger than that of the Baghdadis, numbering between 6,000-8,000 persons by the 1930s. The Russians, moreover, came to Shanghai well after the Sephardim were established there. As Ashkenazim and Russians, they were a different community both culturally and linguistically. A systematic history of this important community is lacking and perhaps impossible to write, due to the scarcity of materials. It will be discussed here in large outlines only. The earliest arrivals may have come to Shanghai after the Russo-Japanese war (19041905), but larger numbers, including Polish Jews, arrived only after the Russian October Revolution of 1917. However, by 1907 there were apparently enough Ashkenazim in Shanghai to form the congregation, Ohel Moishe, on the prem-

Shanghai: Oriental Press, 1933, pp. 496-501. For Ellis Hayim's biography, see pp. 209-210.

56 JDC, file 458, Speelman, Hayim, Mendel Brown to M. Troper, JDC, Paris, December 14, 1939, $8 \mathrm{pp}$. This long letter does not state who was heading the other six committees established at the time.

57 The Relief Society was established as early as December 1934 with Dr. Bernhard Rosenberg, Fritz Kauffmann, E. Lazarus, Dr. Karl Mosse and M. Neumann, to help refugees arriving in Shanghai. This information according to Ernst Pollak, "Menschen die uns halfen," Shanghai Jewish Chronicle, Special Number, March 1940 p. 6. By 1938, the "Relief Society" was under the direction of Dr. Kurt Marx. According to CAHJP, 76.1, Rundschreiben no. 365, January 1939, its name was changed to Relief Society for German and Austrian Jews. See also YVA, 078/58, Heinz Ganther, Günther Lenhardt, eds., Drei Jahre Immigration in Shanghai, Shanghai: Modern Times Publishing House, 1942 , p. 14. 
ises of the Sephardi Shearit Israel synagogue. In 1927, the Russian congregation moved to its own premises on Ward Road (now Changyang Lu) in the Hongkou section of the International Settlement. ${ }^{58}$ The real growth of the community took place in the 1920s with the appointment of Rabbi Meir Ashkenazi, who came to Shanghai in 1926 from Vladivostok; the organization of a burial society in 1922; the acquisition of their own cemetery on Baikal Road (now Weiming Lu); and the establishment of secular clubs. ${ }^{59}$ The Shanghai Jewish Communal Association (Ashkenazi) held its first general meeting in June 1931. In its constitution and by-laws, printed in English, Russian, and Chinese, the association declared that it was "the official representative of the Ashkenaz Jewish population in dealing with Municipal or Government institutions ...” Its activities were to include educational, charitable, and religious affairs. ${ }^{60}$ At about the same time, in 1931 or 1932, the Jewish Club was founded that sponsored sports activities as well as theatrical performances. The younger generation participated in Zionist organizations, “Kadimah” and "Betar," the latter especially emphasized physical training and sports. Their model was Vladimir (Ze'ev) Jabotinsky (1880-1940). ${ }^{61}$

The Russian Jews lived for the most part in the French Concession where they engaged in import-export and were reasonably well-to-do businessmen and store owners. But wealthy individuals comparable to those in the Sephardi community did not exist among Russian Jews. Moreover, the Ashkenazi population that lived in Hongkou and Yangzipu - craftsmen, small store keepers, or boardinghouse owners - suffered great losses both in 1932, when Japanese bombs fell on Hongkou and Zhabei, and during the Sino-Japanese hostilities in 1937. The community was hard pressed during those years to find means of supporting newly destitute families in their midst, ${ }^{62}$ who fled to the more se-

58 David Kranzler, Japanese, Nazis and Jews, the Refugee Community of Shanghai, 1938-1945, New York: Yeshiva University Press, 1976, pp. 60-61.

59 Ibid.

60 "Constitution and Bye-Laws of the Shanghai Jewish Communal Association (Ashkenazi," Pamphlet, Shanghai: Nashe Zarya, 1931. Representatives of the association were: Dr. I. Rosenzweig, M. Vipkovsky, R. Poliak, H. Kammerling, E. Hirsch.

61 Marcia R. Ristaino, Port of Last Resort, The Diaspora Communities of Shanghai, Stanford: Stanford University Press, 2001, p. 67 and Rena Krasno, "History of Russian Jews in Shanghai," in Malek, ed., Jews in China, p. 335.

62 JDC, file 456, Rabbi M. Ashkenazi to Mr. Alkow, August 23, 1937. Ashkenazi was asking the JDC for support in this difficult situation. Also, JDC, file 456, excerpts from letter by Joe Hollzer, Shanghai, to Judge H. A. Hollzer, Los Angeles, December 25, 1937, mentions Russian Jewish emigrants whose poverty has reduced them "almost to savagery." 
cure areas in the French Concession. Thus the Shanghai Jewish Communal Association could not be expected to render much help when the Central European refugees arrived in 1938.

The community took special pride in the large participation of Russians in the Shanghai Volunteer Corps (SVC). First formed in 1853, it eventually included volunteers and units from twenty seven countries, including a Chinese and Jewish company, and consisted of 2.300 men. ${ }^{63}$ The Jewish company was formed in 1932 and 1933 and consisted of 120 former scouts and "Betar" members. N. S. Jacobs (died 1977) became its commander, R. B. Bitker (a decorated veteran of the Russian army) and M. Talan were the company's sergeants. The chaplain was Mendel Brown, the rabbi of the Sephardi congregation. On their uniform collars the Shanghai Volunteers wore a Magen David to identify them as a Jewish company. The SVC ceased to exist after the outbreak of the Pacific War and was officially dissolved in February $1942 .{ }^{64}$

The Russian community participated little, if at all, in the initial relief efforts on behalf of the Central European refugees set in motion in 1938. Nor did they found an organization of their own to help the new arrivals. As mentioned earlier, the lead to do so was taken by the Sephardi community. ${ }^{65}$ The two major organizations that were active from the fall of 1938 in Shanghai were the Committee for the Assistance of Central European Jews in Shanghai and the International Committee for Granting Relief to European Refugees, also known as the International Committee (IC), or the Komor Committee. This committee was established in August 1938 by Paul Komor (1886-?), a Hungarian gentile, who had set up his own trading company in 1937. Much of the work of the IC consisted of registering the new arrivals and keeping individual records as well as cooperating with the SMP and the German Consulate Gen-

63 J. V. Davidson-Houston, Yellow Creek, the Story of Shanghai, London: Putnam, 1962, p. 141.

64 Benis M. Frank, "The Jewish Company of the Shanghai Volunteer Corps Compared with Other Jewish Diaspora Fighting Units,” 1992, pp. 20-22. Unpublished paper, by permission of author. A. G. [probably Anna Ginsbourg], "Evrey-grajhdane i patrioty Shanghaia (Citizens and patriots of Shanghai)," Nasha Zhizn, June 6, 1941; Ristaino, Port of Last Resort, pp. 62-66, and I. I. Kounin, comp., Eighty Five Years of the Shanghai Volunteer Corps, Shanghai: The Cosmopolitan Press, 1938, pp. 215-216. I thank Benis Frank for making the book available to me.

65 Kranzler, Japanese, Nazis and Jews, p. 94 states that the Sephardi and Russian Jews cooperated in establishing the "Committee for the Assistance of European Jewish Refugees in Shanghai," but there is no evidence in the letter, cited above, n. 57, that Russian Jews participated in the meeting. 
eral whenever necessary. ${ }^{66}$ The Relief Society (previously Hilfsfond), headed by Dr. Kurt Marx, continued its work under the auspices of the CAEJR until its dissolution in early $1939 .{ }^{67}$

In addition to the CAEJR and the IC, the HICEM (HIAS) branch in Shanghai, headed by Meir Birman (1891-1955), established its operation in fall 1939. HICEM did not duplicate the work of the other two agencies; its sole function and a formidable task it was - was to bring as many endangered Jews as possible to the safe haven of Shanghai and move those who had visas - or were able to obtain them - to other destinations. Although Sir Victor Sassoon generously contributed to refugee relief work, the activities of the three relief associations were funded $90 \%-100 \%$ by the JDC from September 1939 on. ${ }^{68}$ After the outbreak of the Pacific War in December 1941 and the conquest of all of Shanghai by the Japanese, the work of these organizations ended. The Japanese-sponsored Jewish aid organization, the Shanghai Ashkenazi Collaborating Relief Association (SACRA), was established in 1943 with Russian Jewish leadership. Its function will be discussed in a later chapter.

\section{Shanghai's Russian and Japanese Communities}

By far the largest non-Jewish communities in Shanghai of the 1930s were those of the Russians and the Japanese. So pervasively noticeable were Russian refu-

66 Ristaino, Port of Last Resort, pp. 104-105. See also JDC, file 457, "Report on Jewish Refugee Problems in Shanghai," by M. Speelman, Chairman of the Committee for the Assistance of European Jewish Refugees in Shanghai, June 21, 1939, Annex I. According to Speelman's report, written in Paris, the IC was established in July 1938.

67 The motives of Kurt Marx for involving himself in relief work were, however, suspect to HICEM (the HIAS bureau, Far Eastern Central Information Bureau for Emigrants, known as DALJEWCIB, its telegraphic acronym) even before HICEM relocated in 1939 from Harbin to Shanghai. See copy of B.S. Barbash's letter to HICEM, Paris, JDC, file 456, August 16, 1938. Barbash's letter is dated July 19, 1938. As the Shanghai representative of HICEM, he accused Marx of fund raising to gain an income, thus bringing "chaos into our [HICEM's] work." In another letter, YIVO, HIAS-HICEM, MKM 15,57, File XV, A-17, Harbin to HICEM, Paris, August 16, 1938, Barbash wrote on July 29 that "Dr. Marx has scented rich soil for speculation," being offered by Kadoorie 300 dollars/month to organize immigration. See also JDC, file 456, no signature, letter from "Hilfsfond" to HIAS, Paris, October 1938, asking urgently for funds. According to Speelman, JDC, file 457, report dated June 21,1939 , Annex I, cited in note 67 , the "Hilfsfond" had already been dissolved.

68 JDC, 33-44, file 456, pages from a long report on organizations and disbursement, p. 172 and JDC, file 456, "Statement of Subsidies made by the J. D. C. April 24 Through March 1938." The JDC subsidized the Shanghai Jewish School once, in July 1926, and 
gee peddlers on the streets that they even appeared in Chinese novels written long after the Russians had gone elsewhere. ${ }^{69}$ The initial Russian population did not consist of refugees, but rather mostly traders and military procurement officials who arrived during WWI. By 1917, this population numbered around 700-800 persons, ${ }^{70}$ and soon increased after several waves of White Russian refugees arrived following the civil war in Russia's far east between 1918 and 1923. The complicated history of the Bolsheviks, the Japanese, and the White forces during these years cannot be recounted here. Suffice it to say that the White Russian armies, including Cossacks, and sailors, eventually fled southward via Vladivostok. As described by Marcia Ristaino, "Refugees had been arriving in Shanghai from the north by train, on foot, by mule, or by ship since the Russian revolution had begun, most of them destitute." ${ }^{71}$ More than 1,000 arrived each year and by 1929 there were more than 13,000 Russian refugees in the city. Thousands more came from Harbin after the establishment of Manchukuo on March 1, 1932, ${ }^{72}$ and by 1939 their number had grown to 25,000.

Although we speak here of a community, it must be remembered that the balance among the Russians was forever shifting between old-timers and newcomers. Those who had settled in Shanghai and even found a means of livelihood more often than not looked askance at the new arrivals. "White Russian refugees did not find in Shanghai a large Russian community able or willing to ease their accommodation into the city. Rather, in many cases, they were shunned by the established locals as "poor relatives'." 73 The Russians settled at first in the cheaper housing of Hongkou and Zhabei. However, after the Japanese bombed these areas causing large scale destruction, most moved to

the Refugee Relief Committee in March 1938. In other years subsidies went to Harbin's Talmud Torah.

69 For example, Cheng Naishan, tr. Britten Dean, The Banker, San Francisco: China Books and Periodicals, Inc., 1992, pp. 128-129.

70 Ristaino, Port of Last Resort, p. 33. There was, of course also the Russian consular personnel since the Russian consulate, established in 1860, was not closed until 1920. Tsarist Russia also had banking interests in Shanghai. The Russo-Chinese Bank was established in December 1895, which may have further increased the Russian presence. See Rosemary Quested, The Russo-Chinese Bank: A Multi-National Financial Base of Tsarism in China, Birmingham: Birmingham Slavonic Monographs, 1977, p. 1. 71 Ristaino, Port of Last Resort, p. 35.

72 The Russian Diaspora generally in the $20^{\text {th }}$ century is estimated between one and two million persons. The many cities in which the people settled for longer or shorter periods of time, including Harbin, are detailed in Karl Schlögel, ed., Der grosse Exodus, die russische Emigration und ihre Zentren 1917 bis 1941, Munich: C. H. Beck, 1994.

73 Ristaino, "The Russian Diaspora Community in Shanghai," in Bickers and Henriot, New Frontiers, p, 195. 
the French Concession, as did the Jewish Russians as well. Thus eventually the French Concession became the cultural as well as the political center of Russian life. Large class differences created divisions among the refugees. The numerous military men were joined by workers, clerks, managers, and the like from the Chinese Eastern Railway who found themselves unemployed when the railway was sold to the Japanese in 1935. There were erstwhile aristocrats, numerous musicians, writers, similar to the Paris Russian diaspora, as well as shopkeepers of many kinds. Most of them, as would be also the case for the Central European refugees at the end of the thirties, found it very difficult to secure employment. Some were able to continue in their military professions. The Russian regiment of the SVC absorbed one hundred fifty men with military background.$^{74}$ Others served as bodyguards, guards, or watchmen. The plight of women was especially severe. Respectable women did not work outside the home, and Russian refugee women, having no choice, were often forced to earn a living as waitresses, taxi dancers, entertainers, or prostitutes..$^{75}$

Not only class differences, but ideological differences as well led to divisions within the community. The majority were, of course, uncompromisingly hostile to the Soviet regime, indulging in the nostalgia of a Russia that had ceased to exist and hoping for its return. Others, however, were susceptible to Soviet propaganda that urged the stateless Russians to obtain Soviet citizenship and return to the homeland. This division, though the pro-Soviet stand did not find many adherents, was exacerbated by the Japanese who sought to capitalize on the Russians' anti-Soviet sentiments. ${ }^{76}$

Just how heterogeneous the community actually was is obvious from the numerous organizations created to help the refugees and the largely futile attempts to unify them under one umbrella organization. The Russian Emigrants Committee, formed in July 1926, under the leadership of Victor Fedorovich Grosse (a former Russian Consul General in Shanghai) faced a daunting task. ${ }^{77}$ When Grosse passed away in 1931, Charles E. Metzler, his vice consul, became head of the Emigrants Committee, but was murdered in 1940, having run afoul of his Japanese patrons. The third leader, Nikolai A. Ivanov, lasted nine months. He too was assassinated in September $1941 .{ }^{78}$ Neither the Russian

74 Kounin, Eighty-Five Years, pp. 242-248, provides considerable background, including photographs, about the Shanghai Russian regiment " $C$ " Battalion.

75 Ristaino, Port of Last Resort, pp. 88-94.

76 Wasserstein, Secret War in Shanghai, p.286.

77 Ristaino, Port of Last Resort, p. 50. Marcia Ristaino has contributed more than anyone else to our understanding of the problems of the extremely diverse Russian refugee community.

78 Wasserstein, Secret War in Shanghai, p. 86; Ristaino, Port of Last Resort, pp. 165-173. 
Emigrants Committee nor its leaders succeeded in unifying the refugee community, and they were unable to prevent the emergence of rival organizations, such as the Council of United Russian Public Organizations.

Despite the difficult conditions of refugee life, the infighting and rivalries, there was no lack of Russian culture. Similar to the Russian Jews, the White Russians established clubs and gave theatrical performances, but unlike Russian Jews they created a major publishing center of Russian literature in Shanghai. Books, literary journals, newspapers, patriotic and religious writings flourished. There were six dailies and a Russian bookstore on Avenue Joffre (today Huaihai Lu) as well as a lending library. There were several schools, several Russian Orthodox churches, including a Russian orthodox cathedral on Rue Paul Henri (today Xingle Lu). ${ }^{79}$ Yet, no matter how prominent some may have been in Tsarist Russia, or how important a role they had in Shanghai's Russian community, these Russians were socially on the periphery of the foreign community. They never became part of the influential and mostly British business community, and no Russian had a significant role in the political structure of the treaty port.

The Japanese community was very different. First, it was not a refugee community and secondly, in the course of time the Japanese became the city's largest community of foreigners, despite being relative latecomers to the Shanghai scene. Unlike the British, Americans, and French, the Japanese never established a concession, but in Hongkou where the majority settled, they eventually reaped all the benefits a concession had to offer.

In 1870, three years after the Meiji Restoration, a Japanese mission was sent to China to conclude a treaty with privileges similar to those of the Western powers. Most significantly, it was to include a most-favored-nation clause and the right to trade and travel in the interior. ${ }^{80}$ Concluded in 1871 , the treaty, however, was disappointing because the privileges stipulating trade, purchase of land, and establishment of consulates, were limited to the ports already opened on the China coast. ${ }^{81}$ It was only after China's defeat in the Sino-Japanese War of 1895 and the subsequent Treaty of Shimonoseki that Japan obtained the treaty rights she sought. That treaty and the 1896 Treaty of Commerce and Navigation gave Japan equality with the other treaty powers,

79 Ristaino, Port of Last Resort, pp. 82-85. John Powell, My Twenty-Five Years, p. 6o, mentions more than a dozen Russian orthodox churches, some richly decorated.

80 Peter Duus, Introduction, “Japan's Informal Empire in China: An Overview," in Peter Duus, Ramon H. Myers, Mark R. Peattie, eds., The Japanese Informal Empire in China, 1895-1937, Princeton: Princeton University Press, 1989, p. xx.

81 Ibid. 
especially the right to establish a concession, which Japan did not exercise. Why they chose not to press a claim for an exclusive concession is not entirely clear, according to Mark Peattie. One plausible reason, he thinks, might be that to obtain a less conveniently located and a less developed area than Hongkou would not be to the advantage of Japanese interests. ${ }^{82}$ Hongkou, though part of the International Settlement, may have seemed a logical choice for Japanese settlement, considering its proximity as well accessibility to the $\mathrm{Hu}$ angpu river wharves. On the other hand, there is probably no single factor that can explain the Japanese preference of Hongkou over other areas. But then, the Japanese authorities may have been confronted with a fait accompli. The first Japanese traders had come to Shanghai (and presumably settled in Hongkou) in 1868; in 1870 there were three Japanese, and by 1894, there were one thousand. ${ }^{83}$ Despite repatriations in times of conflict and fighting between Japanese and Chinese, the Japanese population soared to 15,551 in 1920, 24,207 in 1930, and 54,308 in 1939, ${ }^{84}$ as business opportunities expanded. The Central European refugees settling in Hongkou after 1938 thus were unwittingly in close proximity to the Japanese population.

The Japanese were essentially a lower middle class community that did not reflect Japanese society at home. As Joshua Fogel remarks, "there were no rural Japanese farmers or a significant Japanese working class in Shanghai." 85 Unlike prosperous Westerners, they did not indulge in a "grand colonial life style" and they lacked the glitter of many Western communities in Shanghai. Above all, they were merchants and traders with few major industrialists who, in any event, appeared only after WWI. ${ }^{86}$ Christian Henriot describes it as a self-contained community "with a strong tendency to preserve a large degree of autonomy vis-a-vis Westerners and the Chinese population. This created the

82 Mark R. Peattie, "Treaty Port Settlement in China, 1895-1937," in Duus, Myers, Peattie, eds., The Japanese Informal Empire, p. 83. See also Joshua A. Fugal, “'Shanghai-Japan': The Japanese Residents' Association of Shanghai,” JAS, Vol. 59, no. 4 (November 2000), p. 944, who suggests that Japanese hesitated alienating other foreign establishments.

83 Christian Henriot, “'Little Japan' in Shanghai: An Insulated Community, 1875-1945,” in Bickers and Henriot, New Frontiers, p. 148.

$84 \mathrm{Ibid}$. and Xu Jie, "Hongkou Ribanren juzhiqu shulun (Presentation of the Japanese quarter in Hongkou)," Shanghai yenjiu luncong (Papers on Shangha” studies), 10 (1996), p. 297.

85 Fogel, “'Shanghai-Japan': The Japanese Residents' Association of Shanghai,” JAS, 59, no. 4 (November 2000), p. 933.

86 Peattie, “Japanese Treaty Port Settlements," in Duus, Myers, Peattie, eds., The Japanese Informal Empire, p. 193. 
condition for the development of a full-fledged Japanese city that offered myriad jobs to people of almost any extraction." Being concentrated in one part of the city together with their shops, firms, and apartments, they lived in an insulated environment and were hardly in touch with Chinese realities. ${ }^{87}$

There were, of course, plenty of commercial and employment opportunities, which attracted Japanese immigrants to Shanghai. Major among these was the textile industry, which grew by leaps and bounds after WWI. Although at the end of the nineteenth and beginning of the twentieth centuries, the Japanese had not been eager to establish cotton manufacture in Shanghai - preferring to export cotton products to China - but when they finally did, manufacturing cotton proved immediately profitable. "By 1930, the Japanese owned more than 40 mills, or about one-third of the 127 mills then operating in China," writes Peter Duus. Two major reasons account for this. The first was the availability of capital for investment in Japan during WWI, when the wartime boom produced considerable profits. The other was the growth and expansion of the Chinese cotton industry and the dramatic increase of Chinese production. Japanese entrepreneurs were fearful that the Chinese production would cut into their profitable exports. ${ }^{88}$

This largely civilian middle class community was, however, deeply affected by Chinese workers' strikes and especially by the anti-Japanese boycotts which became a feature of Shanghai life from 1915 on. And much to the surprise of the Westerners in the settlements, the usually placid Japanese rioted in January 1932, attempting to force the Japanese authorities to take action against the Chinese. When a mob attacked policemen of the SMP and marched on the Japanese Consulate General, the North China Herald report called it an "extraordinary development in the Sino-Japanese situation which had hitherto failed to disturb the peace and security of the International Settlement ..." 89 The writer's surprise also reveals, however, the ignorance of Westerners about the mood in the Japanese community since 1927. Since that date, the Special Naval Landing Party had become a permanent fixture in Shanghai's Japanese areas and should have been noted due to its increasingly close ties with the Japanese community by means of para-military groups. After the 1932 hostilities, the Special Naval Landing Party erected permanent barracks in Hongkou that could hold up to 2,000 men, tanks, and armored cars. For the next five

87 Henriot, “'Little Japan' in Shanghai," in Bickers and Henriot, eds., New Frontiers, pp. $156-157,164$.

88 Duus, "Zaibabo: Japanese Cotton Mills in China," in Duus, Myers, Peattie, eds., The Japanese Informal Empire, pp. 79, 81, 84.

89 “Serious Sino-Japanese Disturbances," NCH, January 26, 1932. 
years, until the outbreak of the Sino-Japanese war in July 1937, it "ran Hongkew [Hongkou] as if it were an exclusive Japanese concession." ${ }^{90}$ In addition, the role of the Japanese Residents' Association as a link in the control of the Japanese community must not be overlooked..$^{91}$

Like the other communities, the Japanese also established schools in Shanghai, including primary as well as vocational schools. These grew in number together with the population, until by late 1940 there were as many as 9,894 pupils enrolled. ${ }^{22}$ Nor were religious institutions neglected. A Shinto shrine, much enlarged after the 1932 hostilities, served the community's spiritual needs. This, being a community of mostly families and unmarried soldiers, parks and their aesthetic appeal, played an important role in the lives of the people. ${ }^{93}$

I have discussed above four especially prominent communities in Shanghai, the Baghdadis, Russian Jews, White Russians, and Japanese. They were prominent either because of their size or because of their wealth, and they are notable because all four were organized as communities with communal and religious institutions. Each community would continue to play a role in treaty port affairs after the arrival of the Central European Jews, who also constituted themselves as several communities. Although dependent in large measure on the good will of their co-religionists, the Central European refugees asserted their separate identities on linguistic or religious grounds. Their increasingly accelerating arrival coincided with one of the most difficult periods in Shanghai's history: the aftermath of the outbreak of the Sino-Japanese war in July 1937. It is to this period that I want to briefly turn now.

\section{Aftermath of the 1937 Hostilities}

A British consular report dated September 27, 1937, provides an excellent description of how the tension mounted in the International Settlement each day in August. On August 10, the Japanese $1^{\text {st }}$ fleet arrived at Wusong, bringing the total to twenty eight Japanese ships at Shanghai. The Japanese garrison of 2,000 men was increased by an additional 1,000. On August 12, British subjects were warned to move inside the International Settlement. Firing broke out in the northern area on August 13, and on August 14, Chinese air raids, missing

\footnotetext{
90 Peattie, “Japanese Treaty Port Settlements," pp. 198-200.

91 See Fogel, “'Shanghai-Japan',” pp. 927-950.

92 Ibid., pp. 930, 939.

93 Peattie, “Japanese Treaty Port Settlements," pp. 195-198.
} 
the Japanese ships, bombed the settlements. By August 17, as described earlier, people were being evacuated from the International Settlement to Hong Kong. The report adds that business was almost at a standstill, although ships seemed to move freely along the river. ${ }^{94}$

By year's end, the Japanese had retreated from Shanghai and the war moved toward Nanjing and Hangzhou. Nonetheless, as another consular report indicated, "a tense situation has arisen which, in some respects, is even more dangerous and harmful to foreign interests than the hostilities which preceded it.” Increasingly, the Japanese asserted themselves and took control, to which the foreign powers saw no way out except to agree. Chinese government offices were closed by the Japanese, including the Chinese telegraph in November 1937; the wireless administration on January 5, 1938; the Chinese post office on March 8, 1938. The areas under Japanese control, Hongkou and Yangshupu, were temporarily closed to foreign and Chinese residence. Moreover, on December 5, 1937, the Japanese set up a new city government, Dadao, with the puppet mayor Fu Xiaoan (1871-1940), who under Japanese supervision assumed power in the Chinese areas of Shanghai. ${ }^{95}$ But despite the seeming calm in the settlements, guerilla activity in the vicinity of Shanghai was common even in 1939, and firing could be heard in the foreign areas. ${ }^{96}$ The immediate aftermath of the war led to the removal of Chiang Kai-shek's Nationalist government from Nanjing inland, first to Wuhan and then to Chongqing. After Wang Jingwei (1883-1944) defected from the Chongqing government in December 1938, he established a rival puppet regime under Japanese guidance in Nanjing in March 1940. ${ }^{97}$

Not only foreign interests, Chinese business interests, too, were badly affected by the hostilities. Industrial and warehousing facilities in Hongkou, Pudong and Yangshupu suffered enormous damage. Zhabei, together with its newly rebuilt civic center (severely damaged in 1932) was again nearly reduced

94 PRO, FO 371/20985, no. 208, September 28, 1937. Report forwarded by the Consul General Herbert Phillips to the British Embassy in Beijing. The report was compiled by Consul J. A. C. C. Alexander.

95 PRO, F0371/22129, "Political Report for the Shanghai Consular District for the Quarter Ended 31 $1^{\text {st }}$ December 1937," and Barnett, Economic Shanghai, p. 26.

96 Barnett, Economic Shanghai, p. 17.

97 Wang Jingwei continues to be controversial in modern Chinese history. Was he a traitor, an opportunist who made common cause with the enemy? Or was he a patriotic nationalist who sought to protect the Chinese people from brutal exploitation by joining the enemy? For a thoughtful exploration of Wang's position, see Lin Hansheng, "Wang Ching-wei and Chinese Collaboration," Peace and Change, Vol. 1, no. 1 (Fall 1972), pp. 17-35. 
to ruin. More than that, both international and national trade suffered great losses. Cargo ships on their way to Shanghai were diverted to other Asian ports, straining warehousing facilities there. Import and export business suffered because credits abroad were withheld and cash withdrawals from Chinese banks were limited for several months after August. Shanghai was described as having "been dealt a staggering blow in physical destruction of property, and in losses in current and future business ..."98 Although coastal shipping and passenger services, as well as shipping to Yangzi ports, which had ceased altogether in August and September 1937, had resumed on a much reduced scale, the Japanese continued to blockade the Yangzi for many months after the fighting had stopped.

The large scale destruction of various industrial installations led to considerable unemployment of Chinese workers, estimated at 600,000 people out of work. ${ }^{99}$ This situation was exacerbated by the destitute refugees that poured into the settlements from outlying areas where fighting had taken place, especially the refugees of Shanghai itself who had been made homeless in the fighting. "Few villages within a 50-mile radius of Shanghai escaped attention and thousands of unfortunate non-combatants were bombed out of their homes. All these displaced persons sought refuge in the foreign settlements," writes Christian Henriot. ${ }^{100}$ The aid extended by several organizations could hardly alleviate the suffering of tens of thousands of needy people. The refugee crisis lasted throughout 1938 as did the pressure of the Japanese on the Shanghai Municipal Council for concessions. When the Central European refugees started arriving at the end of 1938 in ever increasing numbers, it must have seemed like the last straw to the beleaguered SMC. Its adamant refusal to aid yet another refugee group (discussed below) must be understood as part of the difficult situation that had arisen as a result of the war. The Jewish arrivals, on the other hand, with little or no comprehension of Shanghai's situation and Chinese politics, deplored Chinese indifference to the suffering and death of the needy that they witnessed daily in the streets. They did not realize that the pictures of abject poverty were those of refugees made homeless in war.

Although the four years between the "undeclared war" and the outbreak of the Pacific War in December 1941 were years of increasing hardship in

98 A. Bland Calder, "Shanghai Trade," IM, January 14, 1938, pp. 23, 18. Calder was the assistant American commercial attaché.

99 Frederic Wakeman, Jr., The Shanghai Badlands, Wartime Terrorism and Urban Crime, 1937-1941, Cambridge: Cambridge University Press, 1996, p. 7.

100 Christian Henriot, "Shanghai and the Experience of War. The Fate of Refugees," European Journal of East Asian Studies, Vol. 5, no. 2 (September 2006), pp. 218-219. 
Shanghai, initially, at least, there were signs of a slight business recovery. Despite being surrounded by occupied Shanghai, the foreign settlements (now termed gudao, or solitary island) continued unoccupied by the Japanese for the next four years. Those Chinese entrepreneurs who could salvage their equipment in the industrial areas, gradually moved their installations into the settlements. The nine textile mills in the concessions in 1936 increased to twenty-three by 1940 . Silk filatures, chemical plants, even paper mills sought the safety of the foreign settlements, as did regional banks. Despite losses, the banks of such cities as Hangzhou, Suzhou, and Wuxi moved to unoccupied Shanghai. According to Parks Coble:

By fall of 1938, the solitary island had become a bustling center of economic activity. Though surrounded by a war-scarred and devastated hinterland, the Shanghai concessions experienced an economic flourishing fueled by the influx of capital and business. While total economic activity in the lower Yangzi suffered, within island Shanghai a boom of sorts occurred. ${ }^{101}$

The boom, however, was of short duration. Increasingly, the Japanese took over Chinese plants and inland shipping was drastically reduced. Although trade between areas occupied by Japan and "free China," the areas held by the Chiang Kai-shek's government, never ceased entirely, it is hard to say how much commerce between them actually contributed to Shanghai's economy. ${ }^{102}$ In any event, by 1941 the boom had ended and production of many commodities dropped precariously as compared to 1936 levels. This situation was accompanied by ever increasing inflation, when both the Chiang government in Chongqing and the Wang Jingwei government in Nanjing began printing money. Inflation had increased at a moderate rate until mid-1939, now began to soar ${ }^{103}$ and had a disastrous impact on the lower classes in the treaty port and the newly arriving refugees. Added to this were the waves of crime and terrorism that swept through Shanghai. Racketeering, gambling, the narcotics trade, prostitution - all of these flourished in Shanghai. As discussed by Wakeman in The Shanghai Badlands, assassinations, bombings, Chongqing and puppet sponsored, were a common occurrence between 1937 and 1941. The treaty port era ended, for all practical purposes, when the Pacific war broke

101 Cobble, Chinese Capitalists, pp. 22-24.

102 Lloyd E. Eastman, "Facets of an Ambivalent Relationship: Smuggling, Puppets, and Atrocities During the War, 1937-1945," in Akira Iriye, ed., The Chinese and the Japanese, Essays in Political and Cultural Interaction, Princeton: Princeton University Press, 1980, pp. 275-285. See also Wakeman, The Chinese Badlands, pp. 7-8, who estimates trade between the Japanese areas and Free China around U.S. \$120 million.

103 Cobble, Chinese Capitalists, p. 29. 
out after the Japanese bombed Pearl Harbor and when the Japanese occupied the International Settlement and more or less controlled the French Concession.

\section{Shanghai-Harbin-Tianjin}

It should not be assumed, however, that the Shanghai communities existed in isolation from other foreign communities elsewhere in China. This was especially true for the Russian Jewish community, which was connected with the two major communities in Harbin and Tianjin.

From the end of the $19^{\text {th }}$ century until the collapse of Japanese military power in 1945, Manchuria developed rapidly, both economically and industrially. Together with it, Harbin grew from an insignificant frontier hamlet into a thriving social and administrative center. Located in present-day Heilongjiang province on the Sungari (Songhuajiang) river, the city also became a multiethnic transportation center. ${ }^{104}$ The construction of the Chinese Eastern Railway (CER) by the Russians in 1898 was a major event that triggered the growth and development of Harbin. Running from Manzhouli through Hailar, Qiqihar to Vladivostok, Harbin was at the hub of the CER and the South Manchurian Railway (ceded to Japan after the 1904-1905 Russo-Japanese War) branching off to Lushun (Port Arthur).

Jews first arrived in Manchuria and Harbin together with the CER personnel. Their initial numbers were augmented after the Russo-Japanese War when Jewish soldiers, conscripted into the Russian army, decided to remain in Manchuria. Pogroms and finally the Russian Revolution of 1917 caused large numbers of both Russians and Jews to arrive. Some moved on to Tianjin and Shanghai, others remained in Harbin. The large number of Russians present in Harbin (200,000 according to one estimate) endowed the city with a distinct Russian character. This, together with its multi-ethnic population - consisting of Chinese, Koreans, Japanese, and various kinds of Europeans, including perhaps 13,000 Jews - made Harbin a lively cosmopolitan city in which bankers, merchants, entrepreneurs of many kinds, and professionals made their homes. In recent decades Harbin is remembered nostalgically in a variety of languages. ${ }^{105}$

104 For an excellent description of the pre-WWI Russian role, see David Wolff, To the Harbin Station, The Liberal Alternative in Russian Manchuria, 1898-1914, Stanford: Stanford University Press, 1999.

105 Thomas, Lahusen, "Remembering China, Imagining Israel: The Memory of Difference,” The South Atlantic Quarterly, Vol. 99, no. 1 (Winter 2000), pp. 253-272. 
As a whole, the Jewish community was relatively well-off. "With material success," wrote Boris Bresler, "came community and cultural institutions synagogues, a cemetery, a home for the aged, support for the sick and for the poor, schools, youth organizations, clubs, publications, dramatic productions and lectures." Such publications as, Sibir-Palestina, a Zionist magazine and the later Evreiskaya Zhizn (Hebrew life) were avidly read. ${ }^{106}$ Among the affluent families of the community were the Skidelskys, whose lumber interests along the CER lines and coal mining enterprise brought them enormous wealth. ${ }^{107}$ Nor was the Kabalkin family far behind. Their wealth derived initially from export trade and in the 1920s from flour milling and the soybean trade.

Yet, the well-being of this thriving community was short-lived. The 1929 depression in America and Europe adversely affected business enterprises geared toward exports, setting in motion the exodus that was accelerated by subsequent events. The Japanese invasion of Manchuria in 1931 and the establishment of the puppet state, Manchukuo, resulted not only in the exodus of the Russian population southward and to Shanghai, Russian Jews left as well. Friends and families were reunited in Shanghai or Tianjin, and the community gradually declined in the next thirteen years. By the end of the war, 2,000 Jews remained in Harbin and most of these departed in the next decade as well for various destinations, among them the United States and Israel. By 1985 the lone survivor in Harbin was probably Hanna Agre, too old to leave the place she called home.

However, when the Jews went to Shanghai, they left behind friends and, no doubt, family members. Although we have no evidence so far, and this remains a topic in need of further exploration, some form of connection continued between members of the communities. In short, it is highly unlikely that families, or members of families, would cease to maintain contact with the place and the people among whom they had lived.

A similar assumption must be made about Tianjin. Although its Jewish community was much smaller than either Shanghai's or Harbin's, never numbering more than 2,500 persons, it consisted mostly of Russian Jews who for the most part had come from Manchuria. In 1917 Tianjin had fewer than ten

106 Boris Bresler, “Harbin's Jewish Community, 1898-1958. Politics, Prosperity, and Adversity," in Jonathan Goldstein, ed., The Jews of China, Armonk-London:

M. E. Sharpe, 1999, Vol. 1, p. 206.

107 The great-grandson of Lev Shmulevich Skidel'skii has written a brief biography of his family when he visited China recently. See his, Robert Skidelsky, "A Chinese Homecoming," Prospect, (January 2006), pp. 36-41. 
Jewish families, but within twenty years, and especially after the Japanese occupation of Manchuria, the Jewish community grew rapidly, in the process building religious and social institutions. ${ }^{108}$

Tianjin's Jews took pride in the Tientsin Jewish School, founded in 1925, under the able leadership of the community by Lev Gershevich (1878-1950). The school's medium of instruction was English and its curriculum was designed to have students continue their studies at European or American universities. Cultural activities were not neglected. Entertainment was provided in the Jewish club "Kunst," founded in 1928, and its library boasted presumably 5,000 volumes in Russian and Yiddish. From 1934 on, the Russian newspaper Nashe Zarya (Our dawn) twice monthly devoted one page to Jewish affairs. Finally, in 1937 the Jewish community began to build a synagogue. ${ }^{109}$

Like Shanghai, Tianjin had its foreign concessions, but unlike Shanghai, most of the Russian Jews lived and worked in the British Concession. Fur trade was by far the most lucrative enterprise, at least until the great 1929 depression. Chinese middlemen obtained pelts in the vast Manchurian forests, bringing them to Tianjin for sorting and processing. From Tianjin they were shipped to American and European markets. Although this luxury trade ceased for all practical purposes after 1929, Tianjin firms rapidly diversified, so that the community was spared the disastrous economic setback of Harbin. ${ }^{110}$

Japan's gradual military expansion into north China following the occupation of Manchuria seems not to have adversely affected the Jewish community. However, the Sino-Japanese war in 1937 brought the Japanese armies to its doorsteps and with it Japanese apprehension about communist activities among the Russian Jewish population. Unlike Shanghai, which experienced a massive Central European refugee influx, in addition to its own refugee problem, Tianjin largely escaped both calamities. On the one hand, Tianjin's Chinese sections did not undergo the bombardment Shanghai had. On the other, the Japanese authorities, fearful of communist infiltration, denied residence permits to most Central European applicants. As had been the case in Harbin and Manchuria where only a few Central European refugees were allowed to

108 Nehemia Robinson, Oifleizung fun di Yidishe kehilos in Chine (Dissolution of the Jewish communities in China), New York: Institute for Yiddish Affairs, 1954, p. 13.

109 A. Isgur, "Yevreskaya kolonia Tientsina za posliednia wiesyat lat (The Jewish colony in Tientsin in the last ten years)," Nashe Zarya, no. 3181 (April 7, 1938), pp. 1-7.

[Clipping bound as pamphlet].

110 A substantial history of the Tianjin community is still lacking. This account is based on my brief essay in Chinese and Jews, Encounters between Cultures, London:

Valentine Mitchell, 2008. 
settle, a mere handful of refugees was allowed to come to Tianjin. ${ }^{111}$ It is doubtful that these had close relatives or friends with whom to maintain contact. I am led to believe, therefore, that a network of relationships, however loose it may have been, connected the Russian Jewish communities of the three cities through their publications in Russian and other means available.

In this chapter I have described the beginning and development of Shanghai as a treaty port and the opportunities it offered to both Chinese and foreigners. Foreigners were few as compared with Chinese and, as Rudolf Wagner argues, state and society were clearly separated in Shanghai. Thus treaty port Shanghai provided the possibility for innovation not found elsewhere. Moreover, "The governmental institutions in the enclaves did not compete with the Chinese government for control over the entire country and thus posed no real colonial threat." Within this context of a "relatively independent public sphere," ${ }^{112}$ the communities described above developed. Linguistically very different from one another as well as from the Chinese, who were the majority in Shanghai, they were able to maintain their identities as distinct groups within the treaty port setting. But ultimately, not only politics but also the economy determined Shanghai's future. The gradual and final Japanese takeover of Shanghai spelled the end of the Baghdadi community, whereas the Russians, both Jewish and non-Jewish, continued to exist as communities as did the Central European refugees. In Shanghai, however, Japanese control over both foreign and Jewish communities became part of Japanese occupation policy. How to control and oversee the Jewish communities was an experience the Japanese gained in Manchuria, China's three northeastern provinces.

\footnotetext{
111 As late as 1941, a German memorandum noted that questions of arrival and residence of J-passport holders (that is Jewish) in north China has not been clarified. Pol 4-5a, Akten der deutschen Botschaft in China, "Über Pass- und Aufenthaltsfragen jüdischer Emigranten aus Deutschland in Nordchina," July 9, 1941, signed Marks, consular secretary. I thank Professor Bernard Wasserstein for making a copy available to me.

112 Rudolf G. Wagner, "The Role of the Foreign Community in the Chinese Public Sphere,” The China Quarterly, no. 142 (June 1995), p. 442.
} 
